\title{
Seed priming of plants aiding in drought stress tolerance and faster recovery: a review
}

\author{
K. P. Raj Aswathi ${ }^{1}$ · Hazem M. Kalaji ${ }^{2}$ Jos T. Puthur ${ }^{1}$ (I)
}

Received: 4 June 2021 / Accepted: 10 September 2021 / Published online: 24 November 2021

(c) The Author(s) 2021

\begin{abstract}
Drought stress exposure adversely affects plant growth and productivity. Various seed priming techniques are experimented to mitigate the adverse effect of drought stress on plant performance. It is a low-cost and sustainable technology that proved to be of immense potential to enhance drought tolerance and increase crop productivity. Drought episodes are followed by recovery through rain or irrigation and help the plants to recuperate from the damages caused by drought stress. The severity of drought-associated damages determines the recovery kinetics of plants. Under the recurrent cycle of drought events, recovery kinetics has immense importance in predicting the stress tolerance potential and survival status of a plant. Many processes like DNA damage repair, de-novo synthesis of nucleic acids and proteins, osmotic adjustment through the accumulation of osmolytes, the potential activity of antioxidant machinery occurring during seed priming play a significant role during recovery from drought stress. Alleviation of the severity of drought stress through the accumulation of osmolytes, the augmented activity of antioxidant machinery, improved photosynthetic performance, and the upregulated expression of stress-responsive genes attributed by seed priming will complement the recovery from drought stress. Although the beneficial effects of seed priming on drought tolerance are well explored, priming influenced recovery mechanism has not been well explored. There is a lacuna in the field of research related to the beneficial effects of seed priming for recovery from drought stress, and that is the focus of this paper.
\end{abstract}

Keywords DNA repair $\cdot$ Drought $\cdot$ Recovery $\cdot$ ROS scavenging $\cdot$ Seed priming $\cdot$ Sustainable

\section{Introduction}

Plants are frequently exposed to multitudes of unfavorable environmental conditions such as excessive light intensity, heat, ultraviolet radiation, drought, cold, salinity, nutrient deficiency and environmental pollutants (Banerjee and Roychoudhury 2017; Martinez et al. 2018; Gharechahi et al. 2019). Drastic and frequent occurrence of stress exposure

Communicated by Johannes van Staden.

Hazem M. Kalaji

hazem@kalaji.pls

$\triangle$ Jos T. Puthur

jtputhur@yahoo.com

1 Plant Physiology and Biochemistry Division, Department of Botany, University of Calicut, C.U. Campus P.O., Malappuram, Kerala 673635, India

2 Department of Plant Physiology, Institute of Biology, University of Life Sciences SGGW, Warsaw, Poland adversely affects plant performance and productivity and thereby causes a negative impact on the food and agriculture system, which fails to meet the demands of the growing global population (Zandalinas et al. 2017; Zhou et al. 2017). The plants growing in these adverse conditions modulate their metabolic processes to maintain normal functionality (Hussain et al. 2019; Ansari et al. 2021). The changes in the morphological, physiochemical, and molecular characteristics of plants help them to withstand the unfavourable conditions during a threshold period in which the plants may be able to rescue themselves from the stress exposure (Song et al. 2019).

The extreme rise in the earth's atmospheric temperature and the subsequent effect of global warming creates a significant impact on global agricultural production by limiting water availability and intensifies the occurrence of the drought period. Among the various abiotic stresses, drought is the most crucial one, which directly affects plant metabolisms, development and productivity (Reddy et al. 2004; Abdel-Ghany et al. 2020). Prolonged and recurrent drought 
episodes may eventually lead to the desertification of arable land and increase the gravity of food scarcity and starvation. Current researches are focused on finding out the best strategy to overcome the cumulative effects of drought stress on crop production and to boost up the overall performance and yield of plants amidst frequent and extreme weather events.

Various strategies like conventional breeding and modern methods such as genetic engineering, mutation breeding, and polyploidy breeding are being experimented to develop plants that can endure environmental stresses. However, these techniques have several limitations, such as huge human resources, biosafety and ethical issues (Jisha et al. 2013). Priming is an alternative technique to overcome these limitations and serves as a means to boost up the stress tolerance potential of plants (Sen and Puthur 2020a; Thomas et al. 2020). Seed priming is the treatment of seeds with different factors of natural and synthetic origin to induce a mild dose of stress (Paparella et al. 2015). Seed treatments prior to germination induce a particular physiological state called primed state, which augments several cellular responses (Wojtyla et al. 2016). As a result, plants are equipped to respond quickly to further stress exposure (Farooq et al. 2020). The seedlings emerging from primed seeds are characterized by early and uniform germination, and an overall enhancement in various growth features can be noted in its life span (Jisha et al. 2013; Huang et al. 2020; Khalaki et al. 2021). Seed priming techniques such as hydropriming, osmopriming, halopriming, UV-B priming, and chemical priming induces mild stress on plants and thereby activating stress-responsive genes and proteins like late embryogenesis abundant (LEAs), that potentially induces drought stress tolerance (Chen and Arora 2013; Sen et al. 2020; Thomas et al. 2020). Studies suggest that earlier mild stress exposure can imprint epigenetic memory in plants and make the plants ready to encounter similar stress or with different stress (Bruce et al. 2007; Ding et al. 2013; Marcos et al. 2018; Hossain et al. 2018).

The transitory nature of stress periods complicates the process of drought stress cascades (Ding et al. 2012; Crisp et al. 2016). Most drought events are brief in nature and are followed by favorable conditions enabling the recovery of plants from stress. At the onset of recovery, most of the modifications induced by drought are reverted to the initial state, and plants try to recover from the damages caused by drought (Zhang et al. 2018; Ammar et al. 2020). The extent of damages induced by the stress determines the recovery kinetics of plants, depending on the threshold in which the plants may be able to re-establish homeostasis upon new minimum favorable conditions (Rivas et al. 2016). Researchers have found that earlier exposure to mild stress, which was termed priming, made plants alert for another event of stress (Bruce et al. 2007). This could be accomplished through the imprinting of priming memory. Treatment of seeds with mild doses of stress agents activates signaling molecules and thereby provides drought stress tolerance to plants. Various reports on the attainment of drought tolerance potential in plants emerged from primed seeds of important crops. But, under the transitory nature of stress periods, the quickness of stress recovery plays a vital role in predicting the survival status of plants subjected to stress. Inherent tolerance potential attributed to various seed priming techniques can reduce the drought-induced damages and may help the plants to speed up the process of stress recovery. As the technique does not use any environmentally hazardous substances, it can serve as an environmentally safe and effective strategy to reduce crop loss due to various stressors. The physiochemical and molecular modulations achieved through seed priming complementing the recovery from drought stress are represented in Fig. 1.

There are scanty records on the beneficial effects of seed priming in the recovery kinetics of drought-stressed plants. This review not only focuses on the priming-induced drought tolerance potential of plants but also deals with the recovery kinetics of drought-stressed plants as influenced by seed priming. Also, it addresses the possible mechanisms by which priming aid in faster and efficient recovery from drought.

\section{Impact of drought stress on plant growth}

Drought stress may affect normal plant growth, stomatal conductance, photosynthetic efficiency, ion homeostasis and causes oxidative damage by the over-accumulation of reactive oxygen species (ROS), impeding normal plant growth (Farooq et al. 2009a; Matos et al. 2010). The oxidative stress caused by ROS generation harms the cell integrity by disrupting cell membranes and eventually leads to the degradation of proteins and nucleic acids (Gill and Tuteja 2010). There exists a delicate equilibrium between ROS generation and their scavenging (Choudhury et al. 2017). Efficient detoxification of ROS is essential for the normal functioning of a cell. Modulation of ROS is carried out with the help of potent antioxidant enzymes like superoxide dismutase (SOD), peroxidase (POD), catalase (CAT), and glutathione reductase (GR), and non-enzymatic free radical scavengers like ascorbate (AsA), glutathione (GSH) and phenolics are also involved in antioxidative function (Mittler et al. 2004; Zandalinas et al. 2017). But under severe stress conditions, this equilibrium is disturbed.

Plants have developed several mechanisms for survival under drought stress. Stress signals elicit the accumulation of compatible solutes as osmoprotectants to maintain osmotic balance and to stabilize the integrity of cellular structures (Bohnert et al. 1995; Choluj et al. 2008). It assists the plants in enhancing their survival status under the environment of 


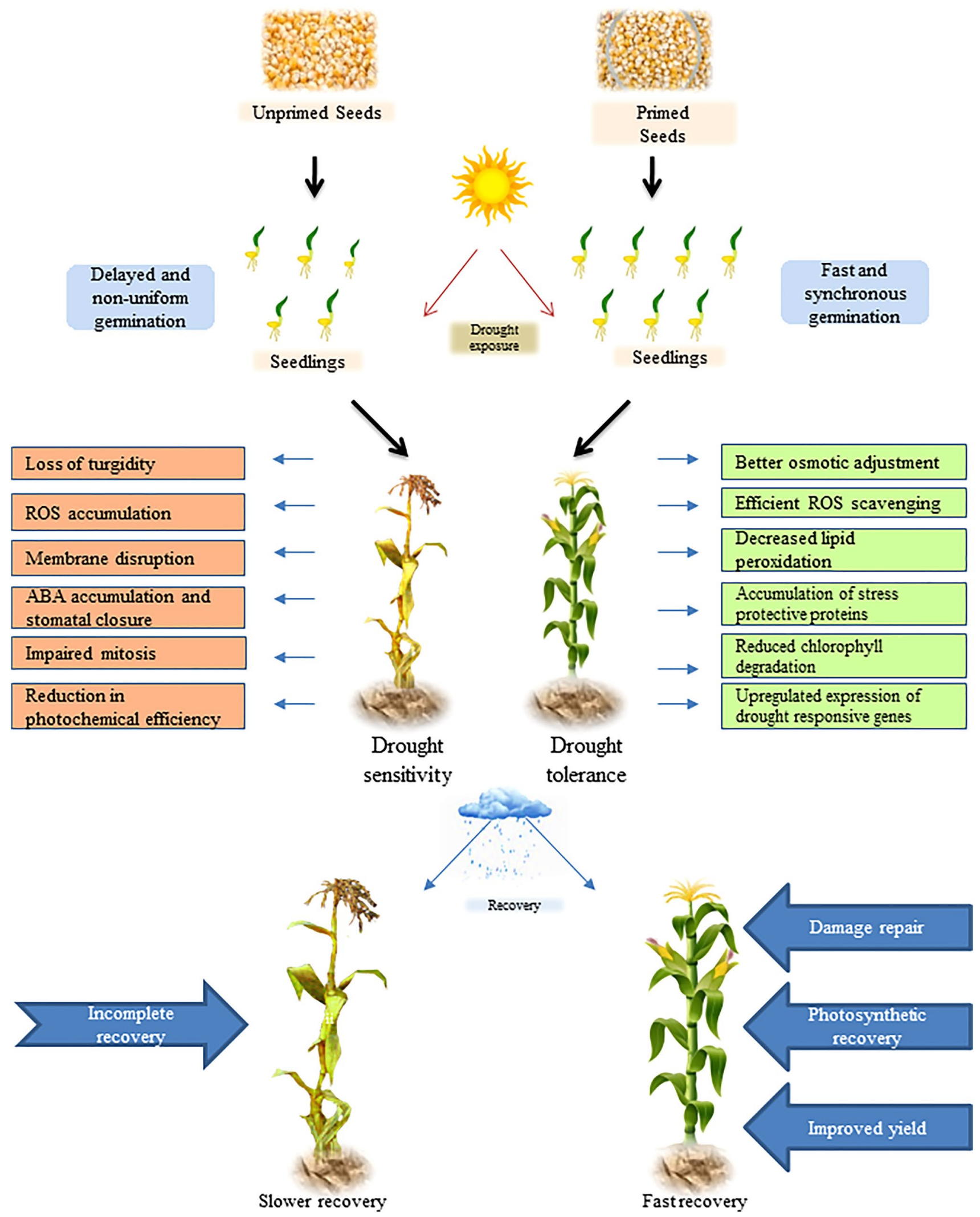

Fig. 1 Augmented drought stress tolerance potential of seedlings emerged from primed seeds alleviates the drought induced damages and thereby facilitates rapid recovery from drought stress upon re-watering through rain or irrigation 
stress (Wang et al. 2019). Better plant water status is maintained by the increased accumulation of osmolytes, aiding in the reduction of oxidative damage (Wang et al. 2019). These osmoprotectants are mainly classified under three chemical categories: sugar and polyols, betaines, amino acids and their derivatives. Furthermore, drought signalling facilitates modifications in the biosynthetic pathways of hormones, especially abscisic acid (ABA). The synthesis of ABA induces a cascade of signalling and gene expression, ending up in the closure of stomata and prevention of excessive water loss (Peleg and Blumwald 2011; Takahashi et al. 2018). Phytohormone signalling pathways (ABA, ethylene and jasmonic acid) are activated during drought stress along with the upregulated activity of drought inducible transcription factors (TFs), which may promote drought tolerance in plants (Wu et al., 2019; Zhu et al. 2019). Accumulation of secondary metabolites during stress periods also serves as an adaptive strategical response to counteract the adverse effects caused by drought conditions (Alhaithloul et al. 2020).

Plant response to drought stress involves complicated signalling machinery (Takahashi et al. 2018). Under a water deficit scenario, plants orchestrate their gene expressions to cope with the unfavourable state. This leads to physiochemical modulations inside the plant cell (Abdel-Ghany et al. 2020). With the depletion of the water supply, drought tolerance responses in plants start to show up quickly (Pandey and Shukla 2015). Deciphering the actual mechanism of drought tolerance is highly essential for the mitigation of the adverse effects of drought stress on plant performance. Drought-modulated genes show complex regulatory mechanisms and subsequent responses during water deficit conditions, imparting tolerance to the plants under stress (Chiappetta et al. 2015; Begcy et al. 2019). The regulation and governing of gene expression occur at different levels, including transcriptional, post-transcriptional, translational, and post-translational levels (Wang et al. 2010; Zhang et al. 2014). Transcriptional signal transduction is mediated through ABA-dependent and ABA-independent pathways. It comprises various $T F s$ such as apetala2/ethylene responsive factor (AP2/ERF), myeloblastosis (MYB), myelocytomatosis (MYC), WRKY, basic-leucine zipper (bZIP), NAC and dehydration-responsive element binding protein (DREB), which in turn activates genes which induce drought tolerance. Mitogen-activated protein kinase (MAPK) and calcium-dependent protein kinases (CDPK) also play an important role in drought signaling (Singh and Laxmi 2015). A proper understanding of these molecular mechanisms would be helpful in improving the genetic potential of plants for drought tolerance.

Expression of stress-responsive genes was directed by several TFs and expression levels of these TFs vary greatly among the tolerant and sensitive genotypes, and upregulation of these are generally shown in tolerant genotypes (Begcy et al. 2019). Drought upregulated TFs help gene expression of stress-specific proteins, which may have a crucial role in alleviating the deleterious effects of drought stress (AbdelGhany et al. 2020). Drought switches on these TFs and activates downstream signalling cascade. Major drought-related TFs include Dehydration Responsive Element Binding protein (DREB) and Abscisic acid Responsive Element Binding protein (AREB), which play a vital role in offering stress survival under water-scarce conditions (Joshi et al. 2016; Kudo et al. 2017; Takahashi et al. 2018).

Another interesting drought stress regulator is LEA proteins, a class of hydrophilic proteins having a potential role in protection against abiotic stresses and are widely distributed in the plant kingdom (Brini et al. 2007; Wang et al. 2007; Magwanga et al. 2018). Dehydrins (Group 2 LEA) are a family of LEA proteins that provide enhanced plant adaptation during drought stress (Chen et al. 2012a, b; Charfeddine et al. 2015). They provide better protection against dehydration stress. Xiao et al. (2007) reported that overexpression of an LEA protein gene, OsLEA3-1, offered drought resistance in rice without a significant yield penalty. In cotton plants, during drought stress conditions, different plant organs showed differential expression levels of LEA genes (Magwanga et al. 2018). The upregulation of genes following drought stress signalling helps to analyze the molecular mechanisms of drought tolerance (Chiappetta et al. 2015).

\section{Priming equips the plants for repeated stress}

Plants are exposed to multiple cycles of stress events. Earlier exposure to stress may help the plant to imprint stress memory and thereby elicit quicker responses on exposure to further stress (Bruce et al. 2007; Marcos et al. 2018). Hence, the transcriptional activities upon the repeated cycle of drought stress are different from that of single stress exposure (Ding et al. 2012). Studies in Arabidopsis thaliana showed transcriptional stress memory through the upregulation of transcription and increased in the level of transcripts of stress-responsive genes upon repeated stress exposure (Ding et al. 2012). A study of dehydration response genes in A. thaliana revealed that there are two categories of genes showing differential transcriptional responses. One group of genes produce transcripts at a similar level during each stress event and others showing upregulated transcript level after each stress exposure. The latter set of genes are termed memory genes. These memory genes finely tune the plants to alert them for the next event of stress (Ding et al. 2013). Expression levels of the stress-responsive genes were higher in plants of primed state than the non-primed state. This 
reveals the phenomenon of complicated stress imprinting by accumulating stress signaling proteins (Bruce et al. 2007). Drought priming before anthesis in wheat enhanced the rate of photosynthesis and activities of ascorbate peroxidase and also reduced membrane damage during grain filling, and this could play a significant role in protection from later occurring stress (Wang et al. 2014). Hence a plant exposed to an earlier stress event can perform better than a plant that did not face any earlier stress. This plant acclimation strategy associated with the stress memory of environmental perturbations elicits signalling processes and offers better protection during further stress exposure.

\section{Seed priming: a means of memory boosting}

The ability to remember past events is highly a boon for organisms to live in a fluctuating hostile environment (Ding et al. 2013; Marcos et al. 2018). Seed priming is a promising strategy to develop stress-tolerant plants by treating seeds with various natural and synthetic factors in mild doses (Jisha et al. 2013; Thomas and Puthur 2020). It induces the triggering of mild stress in plants and thereby alerts the system and partially activates stress-responsive genes and proteins that potentially induce stress tolerance (Chen and Arora 2013). It is well documented that priming promotes early and uniform germination of seedlings by reducing the seedling emergence time and improve the performance and productivity of seedlings that emerged from the primed seeds (Farooq et al. 2013; Jisha et al. 2013). Studies in Oryza sativa revealed that seed priming techniques improve the tolerance potential of tolerant varieties and provide stress tolerance to sensitive varieties (Sen and Puthur 2020a). In both these cases, the priming carried out in the seed stage allows the priming effects to be carried over to the seedlings, which is a clear indication that priming imprints are carried over to different stages of the life cycle of a plant (Sen and Puthur 2020b).

It is possible to develop stress memory in plants through priming strategies, which hasten the molecular responses related to stress tolerance upon subsequent stress exposure. It was also established that the priming memory gets passed from parents to the progeny (Wojtyla et al. 2016). This transgenerational memory provides stress tolerance to the proceeding generations, and it is being studied that whether it will pass on from generation to generation in equal vigour or will it fade off with passing off the generations. Beneficial effects of priming could get imprinted in plants after exposure to the stress exerted by the unfavourable environment (Martinez-Medina et al. 2016) and would help the plant for the augmentation of abiotic stress tolerance response, on being encountered with the same stress or even different stress. The effect of various seed priming techniques and the physiological and molecular responses of primed plants towards drought stress are highlighted in Table 1. Stress tolerance mechanisms attributed through seed priming strategies in turn compliment the process of drought recovery.

\section{How seed priming complement recovery from drought stress}

Drought stress is followed by a favorable period with water availability by rain or irrigation, and plants try to recover. During recovery from stress, plants need to recover from the damages caused by drought. The severity of the drought and the extent of damage caused by the stress determine the recovery kinetics of plants (Rivas et al. 2016). The lesser the damage induced by drought, the more will be the rate and kinetics of recovery (Chen et al. 2016). Hence drought recovery has a vital role in plant drought stress adaptation. Studies revealed that various priming techniques such as hydropriming, osmopriming, UV-B priming and chemical priming generally experiment for the enhancement of drought stress tolerance in plants (Wojtyla et al. 2016). The same priming techniques could be equally good in aiding the plant for a quick and effective recovery from drought stress. It will be interesting to see what all features and effects of priming would aid the plant for recovery from drought stress.

\section{Priming-mediated osmolyte accumulation and recovery kinetics}

Plants being highly susceptible to environmental conditions, maintenance of better water status is a prerequisite for drought stress recovery (Blackman et al. 2009; Dien et al. 2019; Ammar et al. 2020). Effective osmotic regulation during drought stress helps to maintain better plant water status and to reduce the membrane damage caused by drought in primed plants (Farooq et al. 2009b). This was mainly accomplished through the enhanced accumulation of compatible solutes such as sugars, amino acids, proline, and glycine betaine during priming (Tabassum et al. 2018; Khan et al. 2019). Greater accumulation of osmolytes indicated a higher tolerance level of plants (Tabassum et al. 2018). Studies revealed that the accumulation of osmolytes during different seed priming techniques provides drought stress tolerance in plants (Khan et al. 2019; Farooq et al. 2020). When encountering stress, sorghum and barley seedlings emerged from osmoprimed seeds increased the production of amino acids, glycine betaines and total soluble sugars (Zhang et al. 2015; Tabassum et al. 2018). Increased levels of proline, total soluble sugars, and total free amino acids were also noted in hydroprimed, haloprimed and UV-B primed rice subjected to osmotic stress (Sen and Puthur 2020a). Enhanced production of proline in primed rice seedlings indicated their ability 
Table 1 Plant response to drought stress influenced by various seed priming techniques

\begin{tabular}{|c|c|c|c|c|c|}
\hline Sl. no. & Plant species & Priming treatment & $\begin{array}{l}\text { Priming dosage and dura- } \\
\text { tion }\end{array}$ & $\begin{array}{l}\text { Plant response under } \\
\text { osmotic stress }\end{array}$ & References \\
\hline 1 & Lens culinaris & Osmopriming- $\left(\mathrm{CaCl}_{2}\right)$ & $1 \%$ for $12 \mathrm{~h}$ & $\begin{array}{l}\text { Early, uniform germina- } \\
\text { tion, accumulate sugar, } \\
\text { calcium, reduced lipid } \\
\text { peroxidation }\end{array}$ & Farooq et al. (2020) \\
\hline 2 & Medicago truncatula & Hydropriming & $2 \mathrm{~h}$ and $4 \mathrm{~h}$ & $\begin{array}{l}\text { Faster and uniform ger- } \\
\text { mination, upregulated } \\
\text { activity of SOD and APX } \\
\text { gene along with FPG } \\
\text { gene involved in base } \\
\text { excision repair }\end{array}$ & Forti et al. (2020) \\
\hline 3 & Arachis hypogaea & Brassinosteroid priming & $0.15 \mathrm{ppm}$ for $8 \mathrm{~h}$ & $\begin{array}{l}\text { Improved yield compo- } \\
\text { nents (number of pods } \\
\text { per plant, hundred pod } \\
\text { weight, hundred kernel } \\
\text { weight) }\end{array}$ & Huang et al. (2020) \\
\hline 4 & Brassica napus & Gibberellic acid & $500 \mathrm{mg} \mathrm{L}^{-1}$ for $6 \mathrm{~h}$ & $\begin{array}{l}\text { Activation of antioxidant } \\
\text { machinery, Increased } \\
\text { yield traits under drought } \\
\text { and reduced MDA } \\
\text { content }\end{array}$ & Khan et al. (2020) \\
\hline 5 & Brassica napus & Melatonin priming & $500 \mu \mathrm{M}$ for $6 \mathrm{~h}$ & $\begin{array}{l}\text { Reduction of } \mathrm{H}_{2} \mathrm{O}_{2} \text { and } \\
\text { MDA content, reduced } \\
\text { yield loss }\end{array}$ & Khan et al. (2020) \\
\hline 6 & Oryza sativa & UV-B priming & $4 \mathrm{kJm}^{-2}$ & $\begin{array}{l}\text { Osmolyte accumulation } \\
\text { and enhanced activity } \\
\text { of antioxidants }(\mathrm{Cu} / \mathrm{Zn} \\
\text { SOD, CatA and APx1) } \\
\text { and stress related proteins } \\
\text { such as HSP90 and } \\
\text { Group3 LEA }\end{array}$ & Sen et al. (2020) \\
\hline 7 & Oryza sativa & UV-B priming & $4 \mathrm{kJm}^{-2}$ & $\begin{array}{l}\text { Improved the activity of } \\
\text { PSI and PSII, upregu- } \\
\text { lated expression of SOD, } \\
\text { CAT and APX genes }\end{array}$ & Thomas et al. (2020) \\
\hline 8 & Brassica napus & Melatonin priming & $500 \mu \mathrm{M}$ for $6 \mathrm{~h}$ & $\begin{array}{l}\text { Enhanced antioxidant } \\
\text { activity, osmolyte accu- } \\
\text { mulation }\end{array}$ & Khan et al. (2019) \\
\hline 9 & Zea mays & Silicon priming & $6 \mathrm{mM}$ for $16 \mathrm{~h}$ & $\begin{array}{l}\text { Increased root and } \\
\text { shoot length, biomass. } \\
\text { Enhanced photosynthetic } \\
\text { activity and activity of } \\
\text { SOD, POD and CAT }\end{array}$ & Parveen et al. (2019) \\
\hline 10 & Hordeum vulgare & Osmopriming $\left(\mathrm{CaCl}_{2}\right)$ & $1.5 \%$ for $12 \mathrm{~h}$ & $\begin{array}{l}\text { Improved plant water sta- } \\
\text { tus, osmolyte accumula- } \\
\text { tion and reduced lipid } \\
\text { peroxidation }\end{array}$ & Tabassum et al. (2018) \\
\hline 11 & Oryza sativa & BABA priming & $1 \mathrm{mM}$ for $6 \mathrm{~h}$ & $\begin{array}{l}\text { Osmolytes and Antioxi- } \\
\text { dant activity enhanced, } \\
\text { photosynthetic efficiency, } \\
\text { nitrate reductase activity, } \\
\text { reduced MDA content }\end{array}$ & Jisha and Puthur (2016a) \\
\hline 12 & Vigna radiata & BABA priming & $1 \mathrm{mM}$ for $12 \mathrm{~h}$ & $\begin{array}{l}\text { Accumulation of } \\
\text { osmolytes, increased } \\
\text { activity of antioxidants } \\
\text { and nitrate reductase }\end{array}$ & Jisha and Puthur (2016b) \\
\hline 13 & Medicago sativa & Osmopriming (PEG) & $20 \%$ for $24 \mathrm{~h}$ & $\begin{array}{l}\text { Improved nutritional status } \\
\text { of plant, nodulation and } \\
\text { nitrogen fixation rate }\end{array}$ & Mouradi et al. (2016) \\
\hline
\end{tabular}


Table 1 (continued)

\begin{tabular}{|c|c|c|c|c|c|}
\hline Sl. no. & Plant species & Priming treatment & $\begin{array}{l}\text { Priming dosage and dura- } \\
\text { tion }\end{array}$ & $\begin{array}{l}\text { Plant response under } \\
\text { osmotic stress }\end{array}$ & References \\
\hline 14 & Oryza sativa & Spermidine priming & $0.5 \mathrm{mM} \mathrm{L}^{-1}$ for $24 \mathrm{~h}$ & $\begin{array}{l}\text { Improved seed germination } \\
\text { and seedling perfor- } \\
\text { mance, Enhanced activity } \\
\text { of SOD, CAT and POD }\end{array}$ & Zheng et al. (2016) \\
\hline 15 & Sorghum bicolor & Osmopriming (PEG) & $20 \%$ for $48 \mathrm{~h}$ & $\begin{array}{l}\text { Osmolyte accumulation } \\
\text { and Antioxidant activity }\end{array}$ & Zhang et al. (2015) \\
\hline 16 & Triticum aestivum & Ascorbic acid priming & $2 \mathrm{mM}$ for $10 \mathrm{~h}$ & $\begin{array}{l}\text { Improved germination, } \\
\text { plant growth, chlorophyll } \\
\text { content, antioxidant } \\
\text { activity and maintain bet- } \\
\text { ter plant water status }\end{array}$ & Farooq et al. (2013) \\
\hline 17 & Brassica juncea & $\begin{array}{l}\text { Hydropriming, chemical } \\
\text { priming }\left(\mathrm{CaCl}_{2}, \text {, hormo- }\right. \\
\text { nal priming }(\mathrm{ABA})\end{array}$ & $100 \mu \mathrm{M}$ for $18 \mathrm{~h}$ & $\begin{array}{l}\text { Osmolyte accumulation, } \\
\text { enhanced activity of } \\
\text { SOD and GR }\end{array}$ & Srivastava et al. (2010) \\
\hline
\end{tabular}

to adjust the osmotic potential. At the time of recovery, it can also serve as a reservoir of carbon and nitrogen (Thomas and Puthur 2019). Moreover, compatible solutes offer protection to macromolecules and stabilize enzymes (Wang et al. 2019). Maintenance of higher water content through the priming-induced augmentation of osmolytes may also help in rapid recovery from drought stress.

\section{Augmented activity of antioxidant machinery facilitates rapid recovery}

The efficient functioning of the antioxidant system is very crucial for alleviating the adverse effects of drought stress (Mittler et al. 2004). Under severe stress conditions, ROS get accumulated inside the cells and cause damages to cellular membranes and biomolecules (Choudhury et al. 2017). Enhanced activity of enzymatic antioxidants and accumulation of non-enzymatic antioxidants helps to reduce the extent of drought-induced damages to the cell (Gill and Tuteja 2010). The lesser the injury to the cellular structure more will be the rate of recovery (Rivas et al. 2016). Pre-germinative events taking place during seed priming activates the antioxidant system to scavenge ROS and reduce oxidative damage (Paparella et al. 2015). This augmentation of antioxidants occurring due to seed priming results in alleviation of the oxidative damage caused by drought stress (Zheng et al. 2016; Khan et al. 2020).

Studies revealed that UV-B priming in rice reduced the content of hydrogen peroxides and superoxides and increased the level of antioxidant potential by accumulating SOD, CAT, APX, ascorbate and glutathione (Sen et al. 2020; Thomas et al. 2020). Augmentation of the mRNA level expression of SOD, CAT and APX were also noticed in UV-B primed rice (Thomas et al. 2020). Similar results were also seen in rice subjected to spermidine priming with increased activities of SOD, POD and CAT (Zheng et al. 2016). Hydropriming in Brassica juncea enhanced the activities of SOD and GR under osmotic stress (Srivastava et al. 2010). Similarly, hydropriming of Medicago truncatula seeds for $2 \mathrm{~h}$ and $4 \mathrm{~h}$ resulted in the upregulated expression of APX and SOD genes (Forti et al. 2020). The activities of antioxidant enzymes such as APX, SOD, POD and CAT were also upregulated in osmoprimed sorghum (Zhang et al. 2015). Seedlings that emerged from the BABA primed seeds of Vigna radiata and Oryza sativa showed enhancement in antioxidant activity (Jisha and Puthur 2016a, b). Yi et al. (2016) suggested that the improved activity of antioxidant machinery helps to protect the cellular structures from drought stress and aid in rapid stress recovery. Drought-resistant variety showed greater modulation of antioxidants and thereby showed faster recovery (Wang et al. 2019). Such a response was reflected in the case of seed priming also, wherein priming offered more stress tolerance to the tolerant variety (Sen and Puthur 2020a). The efficient functioning of antioxidant machinery attributed to various priming techniques will certainly help plants to recover and restore their normal activity as earlier as possible, on being relieved from stress.

\section{Priming aids in faster photosynthetic recovery}

Among the various biochemical processes, photosynthesis is highly sensitive to drought and more responsive to recovery (Hayano-Kanashiro et al. 2009; Zhang et al. 2018). Photosynthetic recovery is the immediate result of re-watering. The extent of stress recovery relies on the pre-drought intensity, duration and plant species (Rivas et al. 2016; Ammar et al. 2020). During drought recovery, plants restore their photosynthetic activity, which can be noted as an increase in the rate of photosynthesis (Zhang et al. 2018). Two weeks 
of drought exposure followed by re-watering resulted in the formation of new leaves, and thereby improve stomatal conductance, chlorophyll content, and net photosynthetic rate of Ficus carica (Ammar et al. 2020). Similar results were also seen in the case of maize seedlings subjected to recovery from drought stress, wherein recovery was indicated by the higher chlorophyll content and maximum quantum yield of PSII photochemistry (Fv/Fm) and lesser injury of photosynthetic apparatus (Chen et al. 2016).

Recovery elevated the transcript level of chlorophyll synthesis-related genes such as Mg protoporphyrin IX methyltransferase $(C H L M)$, porphobilinogen deaminase $(P B G D)$, glutamate-1-semialdehyde aminotransferase (GSA), 5-aminolevulinic acid dehydratase $(A L A D)$, coprogen oxidase $(C P O)$ and chlorophyll synthase $(C H L G)$, at the same time decreased the transcript level of chlorophyll degradationrelated genes (red chlorophyll catabolite reductase $(R C C R$ ), pheophorbide a oxygenase $(\mathrm{PaO})$, pheophytinase $(\mathrm{PPH})$ and non-yellowing 1 (NYE1), in Craterostigma plantagineum (Liu et al. 2019). According to Yi et al. (2016), rapid photosynthetic recovery upon re-watering the cotton plant was attributed to the stability of photosystems. Similarly, Hura et al. (2018) showed an unchanged level of rieske protein of cytochrome $b_{6} f$ complex during drought as well as re-watering and was found to be one of the reasons for the complete recovery of winter triticales after stress exposure. In contrast, a prolonged drought event may lead to the destruction of chloroplast structure, and hence the recovery process becomes incomplete. Hence the duration and severity of stress determine the rate and kinetics of recovery (Miyashitha et al. 2005). Priming has a role in reducing the severity of stress and thus supporting a quick recovery.

Various seed priming techniques improved the photosynthetic performance of different plants, such as BABA priming and hydropriming in Vigna radiata (Jisha and Puthur 2016b, 2018), biopriming and osmopriming in barley (Tabassum et al. 2018), ascorbic acid priming in wheat (Farooq et al. 2013). According to Sen et al. (2020), UV-B priming of rice seeds reduced the photosystem damage in seedlings subjected to osmotic stress. The rehydration behaviour of tolerant and susceptible genotypes varies greatly during drought recovery. Improved photochemical activity and leaf gas exchange are shown by the tolerant variety helped to reduce the photosynthetic damage during drought stress and favoured early recovery (Rivas et al. 2016). Tolerant genotypes showed rapid recovery in terms of net photosynthetic rate, stomatal conductance, and plant water status (Hayano-Kanashiro et al. 2009). This was supported by the fact that greater modulation in the expression of differentially expressed genes encoding different TFs occurs in the tolerant genotype during drought and subsequent recovery (Hayano-Kanashiro et al. 2009; Zheng et al. 2010; Zhang et al. 2018). Likewise, seed priming of rice with UV-B radiation improved the photochemical efficiency of photosystems in the tolerant variety more profoundly than in the sensitive variety (Sen et al. 2020). Priming induced improvement in the photosynthetic efficiency by reducing the damages to the photosynthetic machinery may aid in rapid recovery from stress and the complete restoration of photosynthesis function.

\section{Priming mediated DNA repair mechanisms enhances the recovery rate}

DNA repair is an important event taking place during the early phase of rehydration. A sudden transition from quiescent to the active metabolic stage causes osmotic imbalance inside the seeds and leads to the accumulation of ROS, which causes breaks in nuclear DNA and subsequent arrest in cell division (Bray and West 2005). Early and controlled imbibition during the seed priming activates DNA repair pathways and antioxidant machinery (Kubala et al. 2015; Forti et al. 2020). This preserves seed vigor and enhances the germination and performance of seedlings that emerged from primed seeds (Paparella et al. 2015). The main repair pathways, such as nucleotide excision repair and base excision repair, are activated during the initial phase of germination, preserving the integrity of the genome (Macovei et al. 2010; Chen et al. 2012a, b; Paparella et al. 2015). Activation of DNA repair mechanism during imbibition, before the onset of cell division, ensured proper germination and seedling growth (Fig. 2). The upregulated expression of AtOGG1, a DNA glycosylase involved in base excision repair in Arabidopsis during seed imbibition, helped to remove DNA lesions and showed enhanced abiotic stress tolerance (Chen et al. 2012a). During seed germination in Arabidopsis, DNA ligase VI and IV genes, AtLIG6 and AtLIG4, had a major role in ligating the double-strand breaks in DNA and determine the quality and longevity of seeds (Waterworth et al. 2010). Similarly, hydropriming of Medicago truncatula seeds resulted in the upregulation of genes involved in DNA damage repairs and antioxidation machinery. Hydropriming treatment for $4 \mathrm{~h}$ enhanced the activity of formamidopyrimidine DNA glycosylase $(F P G)$ involved in base excision repair (Forti et al. 2020). Accumulation of tubulin subunits upon hydropriming and osmopriming in Arabidopsis seeds also indicated the role of seed priming in the reactivation of the cell cycle (Gallardo et al. 2001).

Similar to the DNA repair processes during early germination, stress recovery also relies on the DNA and organelles' damage repair mechanism. During recovery, plants rearrange most of the metabolic pathways to repair drought-induced damages (Chen et al. 2016). Recovery was aided by the reactivation of cell cycle events (Wojtyla et al. 2016). The accumulation of glycine betaine and proline in Beta vulgaris at the final stage of drought event 


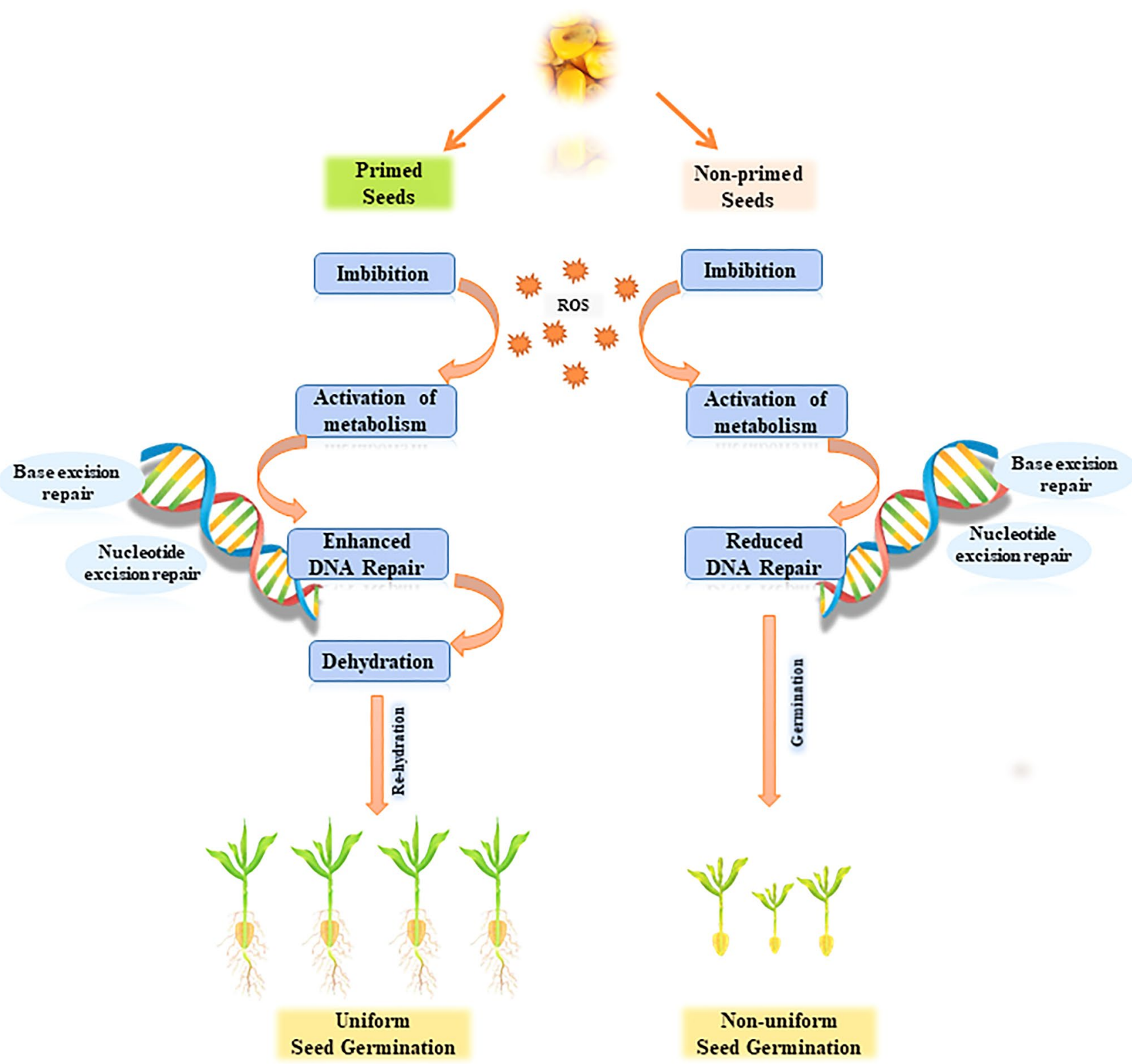

Fig. 2 Priming mediated DNA repair mechanisms enhances seeds quality and vigour and as a result, the seedlings emerged from primed seeds shows improved performance and uniform germination

indicated their role in the repair of damage rather than osmoregulation (Wedeking et al. 2018). Similar results were also found in cowpea, wherein an increase in the content of proline only at the time of severe stress indicated that they are not only involved in osmotic adjustment but assisted in damage repair (Souza et al. 2004). Proper DNA and organelle damage repair mechanism activated during the seed priming techniques helps to reduce the deleterious effects of rapid rehydration and also improves the tolerance and subsequently enhances the rate and kinetics of stress recovery, just as in the case of seeds subjected to rapid hydration during germination.

\section{Beneficial effects of priming memory to encounter recurrent stress}

Stress memory is a boon for plants to cope with the recurrent cycle of stress and recovery (Ding et al. 2013; Liu et al. 2019). More accumulation of stress-related genes or proteins upon repeated stress exposure reveals the role of earlier stress exposure to imprint memory in plants and the subsequent development of alertness for memorizing the past event (Liu et al. 2019). Several studies have shown that prior drought stress exposure results in the imprinting of the stress memory in plants (Ding et al. 2012; Marcos et al. 
2018). The role of certain genes in stress memory was evident in a study carried out with the resurrection plant Craterostigma plantagineum. When subjected to multiple cycles of dehydration and recovery, it was showed elevated transcript level of stress-induced LEA genes (LEA-like 11-24, LEA2 6-19 and LEA 13-62), and early dehydration responsive 1 (EDR1), upon each dehydration stress and the memory persist up to 6 days of recovery (Liu et al. 2019). Similarly, Ding et al. (2012) showed an increased rate of transcription of stress response genes (RD29B and RAB18) in Arabidopsis on exposure to each cycle of stress, and it was found that the memory related to this gene lasts for 5 days during recovery.

Earlier stress exposure equips the plant for the upcoming stress similar to the past stress (Gamir et al. 2014). This sort of prior exposure to mild stress is called priming. Seed priming with a mild dose of stress agents activates stress memory in plants and thereby equips them for a future stress encounter (Bruce et al. 2007). Retention of the stress tolerance mechanism even after recovery is helpful to keep the plant ready for repeated drought events (Nawaz and Wang 2020). The priming memory can be accomplished through epigenetics and metabolic imprinting (Schwachtje et al. 2019). Priming mediated stress memory helps to improve the tolerance potential of plants through the accumulation of stress-responsive proteins and activation of genes, which will facilitate quick recovery from stress. The exposure of mild stress during the vegetative stage of a plant exhibits an enhanced tolerance potential during the second exposure to severe stress. Evidence for this was found in wheat plants subjected to drought priming during the tillering stage, showing enhanced performance in terms of higher photosynthesis rate and antioxidants and reduced yield loss upon further drought exposure at the time of post-anthesis. This implicates the possibility of stress memory getting imprinted during priming (Abid et al. 2016).

Studies showed that the rate of recovery largely depends on pre-stress exposure. According to Ammar et al. (2020), the plants subjected to earlier stress regain their growth through the emergence of new leaves and subsequently improved photochemical activities during stress recovery than the plants that did not encounter any past stress experience. This finding suggested the role of pre-stress exposure in the recovery kinetics of plants. Leaf proteome analysis in Beta vulgaris showed that some stress-related proteins did not revert very quickly during drought recovery, and the involvement of these proteins was found to be more involved in drought memory and acclimation (Schneider et al. 2019). A second increase in the amino acids content was noted in the leaves of $B$. vulgaris after the transient normalization of most of the metabolites within 8 days of re-watering. This second increase of amino acids might be indicating an imprint left behind after a stress episode, which turns out to be beneficial during future drought episodes
(Wedeking et al. 2018). Hence, metabolic imprinting also has a vital role in inducing tolerance in the altered environment (Schwachtje et al. 2019).

Accumulation of several TFs and signaling proteins during seed priming provides greater stress tolerance and crosstolerance to the seedlings that emerged from primed seeds (Chen and Arora 2013). The findings of our own research group have provided the first report on the effectiveness of UV-B seed priming in stress imprinting and cross-tolerance mechanism of rice seedlings, where cross-tolerance was shown towards $\mathrm{NaCl}$ stress after imparting UV-B priming to the seeds (Thomas et al. 2020). Activation of stress signalling pathways through the enhanced expression of heat shock proteins (HSP) and LEA proteins was reported in UV-B primed seedlings of rice (Sen et al. 2020). Augmentation of such stress-responsive genes and proteins during seed priming enhances the tolerance potential towards abiotic stresses and makes the plants alert for future stress events. Hence, under the recurrent cycle of drought stress and recovery, stress memory is highly beneficial for plants to shift their metabolism in accordance with the changing circumstances.

\section{Priming and retention of stress memory}

Epigenetics is an interesting concept in the field of stress biology. Modifications in the chromatin architecture governs the gene expression by regulating the accessibility of genes for transcriptional machinery (Banerjee and Roychoudhury 2017). These modifications involve DNA methylation, histone modification or chromatin remodeling (Bruce et al. 2007). Abiotic stress exposure alters the expression levels of various TFs involved in stress metabolism. Long-term changes in gene expression is also brought about by the epigenetic modifications enabling the plant to retain some memory regarding the past experience, even after the relieving of stress (Bruce et al. 2007). These heritable epigenetic modifications retain stress memory through genome imprinting and lead to the persistence of memory over multiple generations. Priming of plants was found to create long-term stress memory in plants (Tabassum et al. 2017). When plants encounter with further stress exposure, this epigenetic stress memory will be helpful for plants to respond quickly and to recover rapidly from drought induced injuries (Abid et al. 2018). Beneficial effects of epigenetic memory in counteracting multiple cycle of drought stress and alleviating the drought induced damages for favouring recovery is provided in Fig. 3.

Even though, some stress marked epigenetic signatures may reset into the initial state upon stress removal, the process of resetting may not occur in full strengths. At the time of recovery, the expression of drought stress induced genes reset to their basal level and this process necessitates 


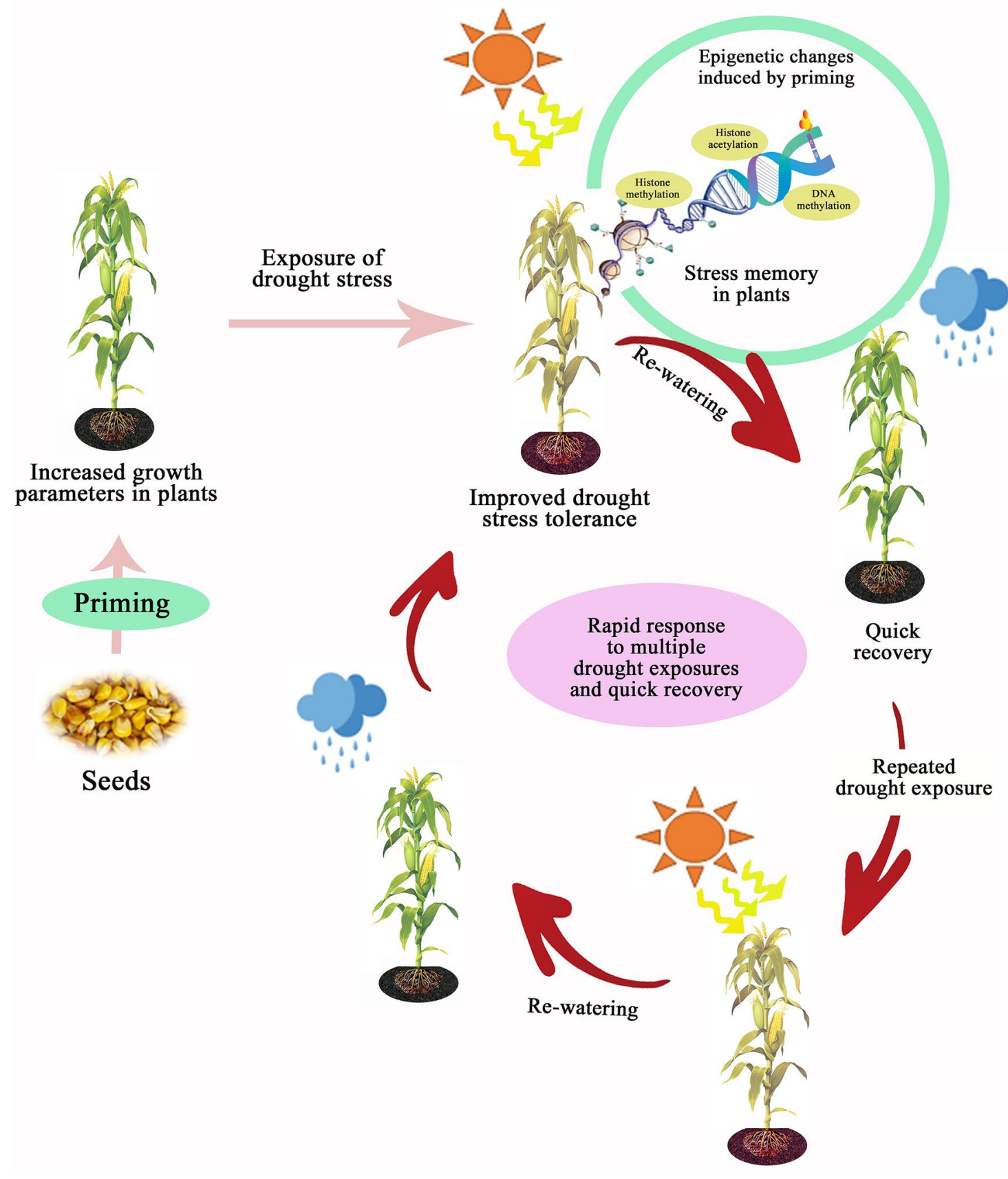

Fig. 3 Epigenetic modifications induced by priming is helping in imprinting stress memory. It is beneficial under recurrent drought exposure and also favours rapid stress recovery

nucleosome rearrangements. During post drought recovery it was examined that an immediate deacetylation occurs at the H3K9ac sites, followed by the eventual elimination of RNA polymerase II. On the other hand, histone H3 Lys4 tri-methylation (H3K4me3), progressively decreased following rehydration but still remained at low levels without total disappearance. Therefore, H3K4me3 can very well serves as a stress related epigenetic marker (Kim et al. 2012). Based on the reversibility, methylation/ demethylations sites differs. During recovery $70 \%$ of the methylation/demethylation sites were restored to their original state, and $29 \%$ of the sites persists even after recovery (Wang et al. 2010) During recovery from stress the level of H3K4me3 decrease but even after the recovery some stress memory is retained (To and Kim 2014). This memory is beneficial in easing the process of drought stress recovery. 


\section{Molecular events during stress recovery can be influenced by seed priming}

Molecular events taking place during stress recovery may be considered similar to the pre-germinative events occurring during seed priming. Hence, the rate and kinetics of drought recovery can be positively influenced by seed priming techniques (Fig. 4). The recovery phase is primarily characterized by the process of damage repair, re-start of cell division, and reactivation of mRNA, and synthesis of new proteins (Dace et al. 1998). Priming in seeds also activates similar events such as DNA repair, activation of antioxidants and de-novo synthesis of nucleic acids and proteins, and metabolic reactivation (Paparella et al. 2015). Drought stress recovery in tomato showed upregulated expression of histone variants, which lead to the reactivation of DNA replication and restoration of cell cycle activity (Iovieno et al. 2016). Likewise, seed priming also involves the activation of specific enzymes, early DNA replication, and synthesis of DNA and RNA (Bray et al. 1989). Which, in turn, contributes to early and uniform germination, improved growth, and performance of seedlings emerged from primed seeds (Parveen et al. 2019; Farooq et al. 2020).
Fig. 4 Physio-chemical events taking place during seed priming and drought recovery. The processes common to both seed priming and recovery reveals the beneficial effects of seed priming for faster recovery from drought stress

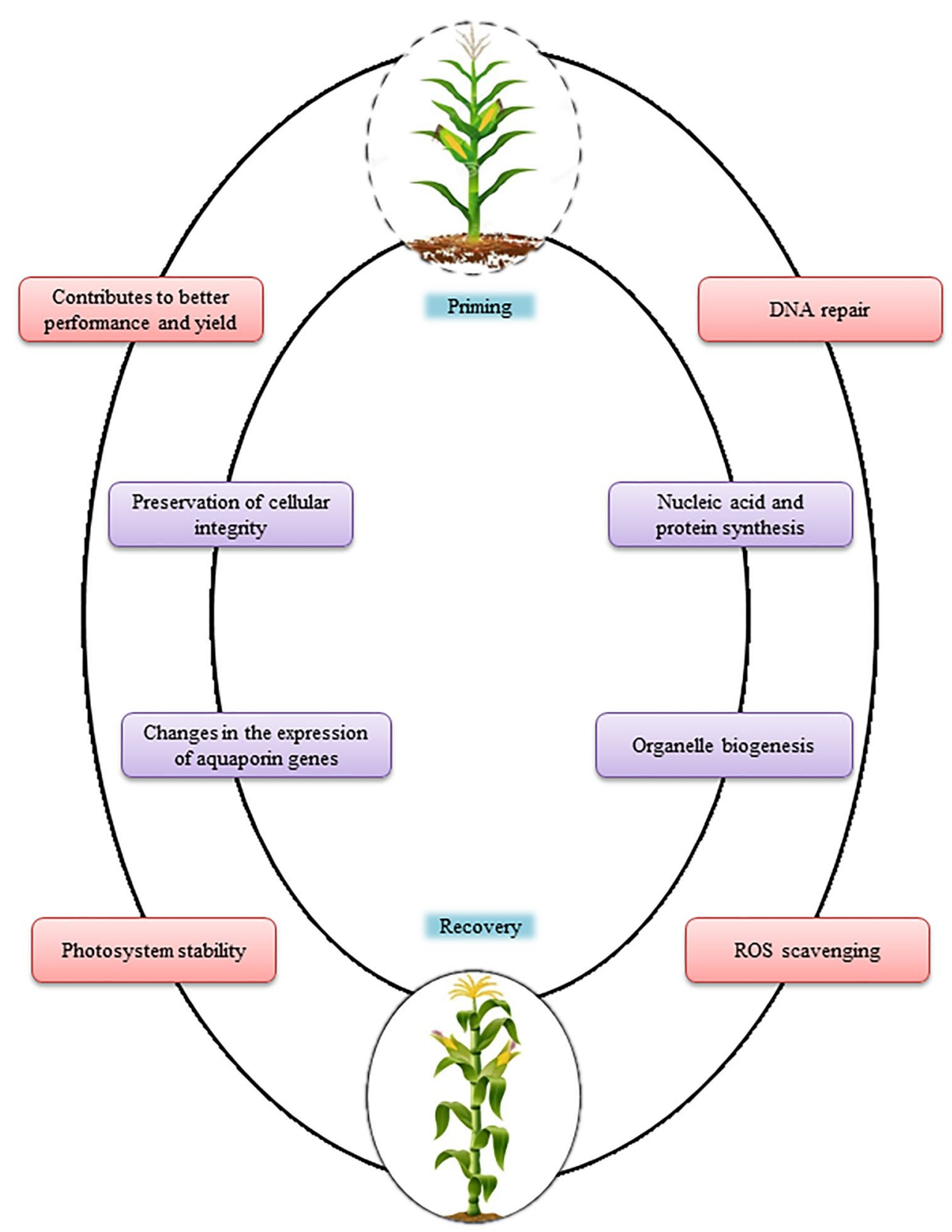


Seed germination triggered the production of ROS. The upregulated activity of antioxidant genes during seed priming complements the process of faster germination and seedling establishment. $\mathrm{Cu} / \mathrm{Zn}$ SOD, CatA and APxI genes were upregulated in UV-B primed rice seedlings (Sen et al. 2020; Thomas et al. 2020). Also, enhanced expression patterns of most stress-response genes such as LEA and HSP were reported in plants subjected to different seed priming treatments. HSP9O and group 3 LEA genes were upregulated in UV-B primed rice varieties (Sen et al. 2020). Similar trends were also noticed in osmoprimed Spinacia oleracea, wherein the relative expression of genes coding for dehydrin-like proteins were upregulated, and it was still more under drought stress (Chen et al. 2012a, b). Enhanced expression of these stress-induced genes in plants subjected to priming and exposed to stress may be advantageous at the time of stress recovery.

During re-watering, photosynthetic genes were upregulated, which leads to photosynthetic restoration and subsequently promotes plant growth (Iovieno et al. 2016). Upregulated expression of FtsH homologue, ATP-dependent zinc metalloprotein is involved in the turnover of the oxidized D1 protein of PSII reaction centre during recovery from drought stress and helps for faster recovery from photosystem damage (Zhang et al. 2014; Iovieno et al. 2016). Evidence suggests that through various seed priming techniques, plants achieve improved photochemical activity and maintains the stability of photosynthetic apparatus even during stress periods. This could serve as one of the possible roles of seed priming in facilitating rapid recovery from stress. The upregulated activity of Drought-Responsive genes $R D I$ and $R D 2$ of AP2/ERF family in the seedlings of primed seeds under drought stress enhanced the drought tolerance potential in rice (Samota et al. 2017). In a different study, expression of PSII gene in Brassica oleracea revealed that the upregulated expression of PSbI in the variety botrylis and $P S b M$ in the variety capitate upon jasmonic acid and methyl jasmonate priming was involved in the formation of PSII dimer and maintains photosystem stability, and this may facilitate rapid photosynthetic recovery upon re-watering (Sirhindi et al. 2020). This finding reveals the role of priming in maintaining the stability of photosynthetic apparatus during the drought, which may turn to be very crucial during the recovery for the quick regain of photosynthetic capacity.

Genes involved in osmolyte synthesis and hormone biosynthesis, aquaporin genes, signalling molecules, and several TFs, modulates their expression during drought and recovery (Bhargava and Sawant 2013; Iovieno et al. 2016). Table 2 list the changes in the expression levels of various stress-related genes during recovery from drought stress. Overexpression of aquaporin gene MaPIP2-7 enhanced the stress tolerance potential through the maintenance of better plant water status (Xu et al. 2020), which is a prerequisite for seed germination. Increased activity of OePIP2.1, a PIP2 aquaporin gene during drought stress recovery, implicates the beneficial role of aquaporin water channels in facilitating water absorption and subsequent recovery from drought (Secchi et al. 2007). There are reports of similar events taking place during seed priming. Upregulation of aquaporin genes SoPIP1;1, SoPIP1;2, SoPIP2;1, and SoסTIP offers drought tolerance in $S$. oleracea upon seed priming with PEG, which in turn favours water imbibition for the initiation of germinative events and further seedling growth (Chen et al. 2013). These sorts of molecular events will turn

Table 2 Expressions of various genes in different plants during recovery from drought

\begin{tabular}{|c|c|c|c|c|}
\hline Sl. no & Plant species & Gene & Expression during recovery & References \\
\hline 1 & Craterostigma plantagineum & $\begin{array}{l}\text { Chlorophyll synthesis (CHLM, } \\
P B G D, G S A, A L A D, C P O \text { and } \\
C H L G)\end{array}$ & Upregulated expression & Liu et al. (2019) \\
\hline 2 & Saccharum officinarum & $\begin{array}{l}\text { Late embryogenesis abundant } \\
\text { (LEA) }\end{array}$ & Increased gene expression & Devi et al. (2019) \\
\hline 3 & Zea mays & $\begin{array}{l}\text { Photosynthetic genes (PSAK and } \\
\text { PSAH-2) }\end{array}$ & Expressions were induced & Zhang et al. (2018) \\
\hline 4 & Camellia sinensis & $\begin{array}{l}\text { ABA biosynthesis (NCEDI and } \\
\text { NCED4) }\end{array}$ & Downregulated during recovery & Liu et al. (2016) \\
\hline 5 & Solanum lycopersicum & $\begin{array}{l}\text { Histone gene families and photo- } \\
\text { system genes }\end{array}$ & Re-activated during recovery & Iovieno et al. (2016) \\
\hline 6 & Vigna radiata & $\begin{array}{l}\text { Pyrroline-5-carboxylate synthetase } \\
\text { (P5CS) }\end{array}$ & $\begin{array}{l}\text { Activity reached to the control } \\
\text { level }\end{array}$ & Sengupta et al. (2013) \\
\hline 7 & Nicotiana tabacum & Dehydrin gene (NtERD1OB) & Downregulated & Dobrá et al. (2011) \\
\hline 8 & Zea mays & $\begin{array}{l}\text { Pyrroline-5-carboxylate dehydroge- } \\
\text { nase }(P 5 C D H)\end{array}$ & Decreased activity & Hayano-Kanashiro et al. (2009) \\
\hline 9 & Olea europaea & Aquaporin gene $(O e P I P 2.1)$ & Upregulated expression & Secchi et al. (2007) \\
\hline 10 & Craterostigma plantagineum & Transketolase $(t k t 7)$ & Increased activity & Bernacchia et al. (1996) \\
\hline
\end{tabular}



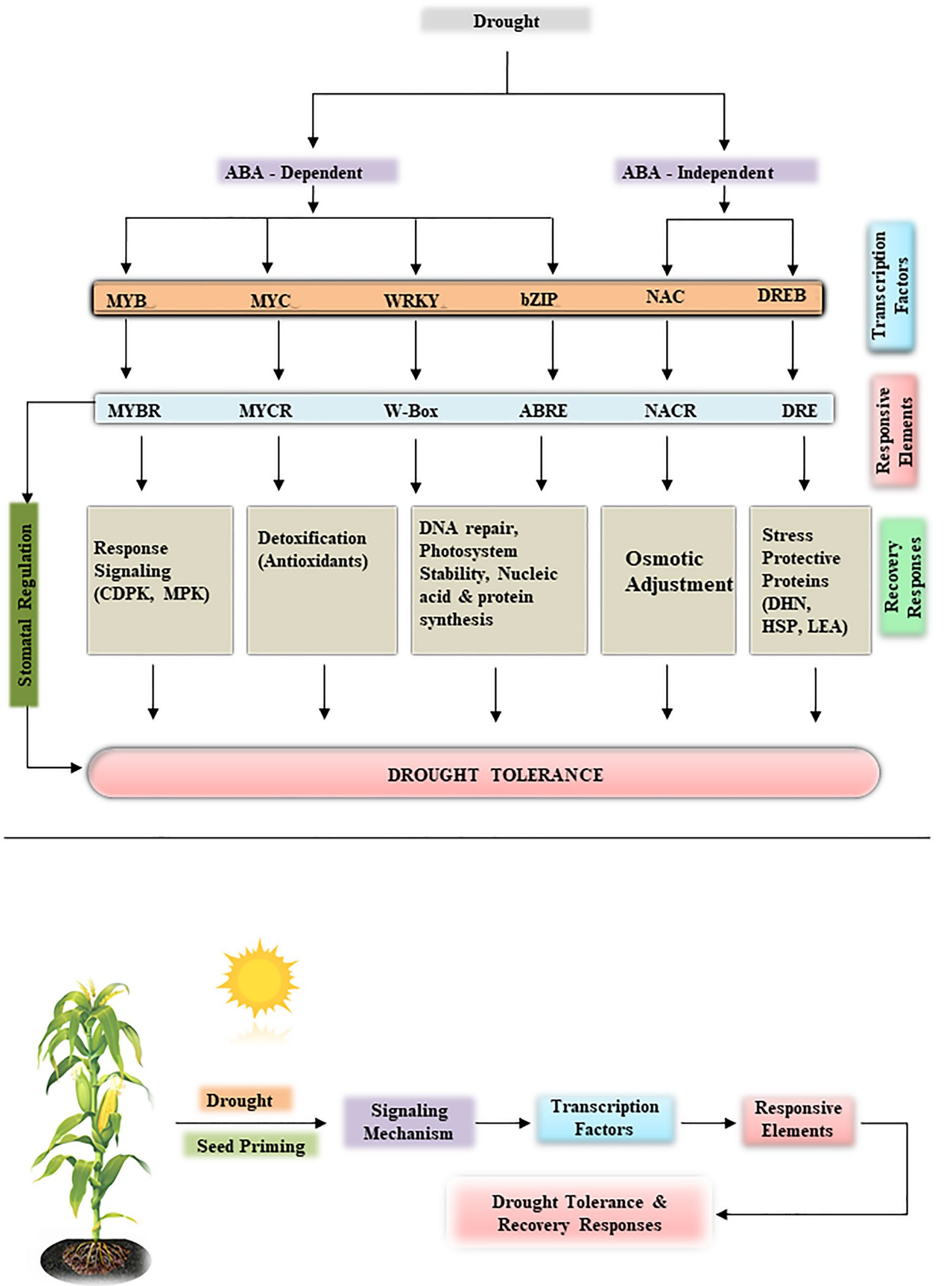
४Fig. 5 Drought stress activate ABA-dependent and ABA-independent signaling pathways, which in turn activates MYB/MYCs, WRKYs, bZIP, NACs, and DREB transcription factors. This positively upregulate genes involved in drought stress tolerance. Seed priming techniques also activates the similar drought tolerance mechanisms and speed up the process of recovery responses in plants

out to be beneficial for the plants not only during the phase of stress but during the recovery from stress. The molecular mechanism of drought tolerance and the possible means of recovery response attributed by seed priming are represented in Fig. 5.

\section{Conclusion and future perspective}

Augmentation of stress tolerance potential through various seed priming techniques is a promising strategy to mitigate the detrimental effects of drought stress on plant growth and productivity. Just as priming enhancing the drought tolerance potential, it can also complement rapid and successful recovery from stress impacts. Maintenance of better plant water status, enhanced antioxidation machinery, improved photochemical efficiency, DNA and organelle damage repair, and denovo synthesis of nucleic acids and proteins attributed by seed priming reduces the severity of drought-induced damages on plant performances. These physiochemical modulations taking place during seed priming could favour most of the processes essential for a plant to recover quickly from drought stress. Hence, at the onset of a favourable environment through rain or irrigation, plants emerged from primed seeds recoup in a faster and improved manner. There is a prominent gap of information regarding the influence of seed priming on the recovery kinetics of plants subjected to drought stress. This eco-innovation augments the inherent stress tolerance potential of plants and thereby contributes towards better crop production. Environmental and ethical safeness offered by various seed priming techniques makes it a promising and sustainable strategy to ensure food security.

Acknowledgements K. P. Raj Aswathi Express sincere thanks to the University Grant Commission (UGC), India, for providing funding in the form of JRF. The authors extend their sincere thanks to the Department of Science and Technology (DST), Government of India for granting funds under the Fund for Improvement of S\&T Infrastructure (FIST) programme (SR/FST/LSI-532/2012).

Author contributions ARKP performed conceptualization, analysis and interpretation of the data, writing-original draft, designing the figures and funding acquisition. JTP provided critical feedback and helped shape the research and analysis aided in interpreting the results, and worked on the manuscript. HK critically revised the manuscript.

Funding This work was supported by the University Grant Commission (UGC), India, in the form of JRF under grant 318224.
This work was supported by the University Grant Commission (UGC), India, in the form of JRF under grant 318224.

Data availability Not applicable.

Code availability Not applicable.

\section{Declarations}

Conflict of interest The authors declare that they have no competing interest.

Ethical approval Not applicable.

Consent to participate Not applicable.

Consent for publication Not applicable.

Open Access This article is licensed under a Creative Commons Attribution 4.0 International License, which permits use, sharing, adaptation, distribution and reproduction in any medium or format, as long as you give appropriate credit to the original author(s) and the source, provide a link to the Creative Commons licence, and indicate if changes were made. The images or other third party material in this article are included in the article's Creative Commons licence, unless indicated otherwise in a credit line to the material. If material is not included in the article's Creative Commons licence and your intended use is not permitted by statutory regulation or exceeds the permitted use, you will need to obtain permission directly from the copyright holder. To view a copy of this licence, visit http://creativecommons.org/licenses/by/4.0/.

\section{References}

Abdel-Ghany SE, Ullah F, Ben-Hur A, Reddy AS (2020) Transcriptome analysis of drought-resistant and drought-sensitive sorghum (Sorghum bicolor) genotypes in response to PEG-induced drought stress. Int J Mol Sci 21(3):772. https://doi.org/10.3390/ ijms21030772

Abid M, Tian Z, Ata-Ul-Karim ST, Liu Y et al (2016) Improved tolerance to post-anthesis drought stress by pre-drought priming at vegetative stages in drought-tolerant and-sensitive wheat cultivars. Plant Physiol Biochem 106:218-227. https://doi.org/10. 1016/j.plaphy.2016.05.003

Abid M, Hakeem A, Shao Y, Liu Y et al (2018) Seed osmopriming invokes stress memory against post-germinative drought stress in wheat (Triticum aestivum L.). Environ Exp Bot 145:12-20. https://doi.org/10.1016/j.envexpbot.2017.10.002

Alhaithloul HA, Soliman MH, Ameta KL, El-Esawi MA, Elkelish A (2020) Changes in ecophysiology, osmolytes, and secondary metabolites of the medicinal plants of Mentha piperita and Catharanthus roseus subjected to drought and heat stress. Biomolecules 10(1):43. https://doi.org/10.3390/biom10010043

Ammar A, Aissa IB, Mars M, Gouiaa M (2020) Comparative physiological behavior of fig (Ficus carica L.) cultivars in response to water stress and recovery. Sci Hortic 260:1081. https://doi.org/ 10.1016/j.scienta.2019.108881 
Ansari MI, Jalil SU, Ansari SA, Hasanuzzaman M (2021) GABA shunt: a key-player in mitigation of ROS during stress. Plant Growth Regul 94:131-149. https://doi.org/10.1007/s10725-021-00710-y

Banerjee A, Roychoudhury A (2017) Abscisic-acid-dependent basic leucine zipper (bZIP) transcription factors in plant abiotic stress. Protoplasma 254(1):3-16. https://doi.org/10.1007/ s00709-015-0920-4

Begcy K, Mariano ED, Lembke CG, Zingaretti SM, Souza GM, Araújo P, Menossi M (2019) Overexpression of an evolutionarily conserved drought-responsive sugarcane gene enhances salinity and drought resilience. Ann Bot 124(4):691-700. https://doi.org/10. 1093/aob/mcz044

Bernacchia G, Salamini F, Bartels D (1996) Molecular characterization of the rehydration process in the resurrection plant Craterostigma plantagineum. Plant Physiol 111(4):1043-1050. https://doi.org/ 10.1104/pp.111.4.1043

Bhargava S, Sawant K (2013) Drought stress adaptation: metabolic adjustment and regulation of gene expression. Plant Breed 132(1):21-32. https://doi.org/10.1111/pbr.12004

Blackman CJ, Brodribb TJ, Jordan GJ (2009) Leaf hydraulics and drought stress: response, recovery and survivorship in four woody temperate plant species. Plant Cell Environ 32(11):1584-1595. https://doi.org/10.1111/j.1365-3040.2009. 02023.x

Bohnert HJ, Nelson DE, Jensen RG (1995) Adaptations to environmental stresses. Plant Cell 7(7):1099-1111. https://doi.org/10. 1105/tpc.7.7.1099

Bray CM, West CE (2005) DNA repair mechanisms in plants: crucial sensors and effectors for the maintenance of genome integrity. New Phytol 168(3):511-528. https://doi.org/10.1111/j.14698137.2005.01548.x

Bray CM, Davison PA, Ashraf M, Taylor RM (1989) Biochemical changes during osmopriming of leek seeds. Ann Bot 63(1):185193. https://doi.org/10.1093/oxfordjournals.aob.a087722

Brini F, Hanin M, Lumbreras V, Amara I et al (2007) Overexpression of wheat dehydrin DHN-5 enhances tolerance to salt and osmotic stress in Arabidopsis thaliana. Plant Cell Rep 26(11):2017-2026. https://doi.org/10.1007/s00299-007-0412-x

Bruce TJ, Matthes MC, Napier JA, Pickett JA (2007) Stressful "memories" of plants: evidence and possible mechanisms. Plant Sci 173(6):603-608. https://doi.org/10.1016/j.plantsci.2007.09.002

Charfeddine S, Saïdi MN, Charfeddine M, Gargouri-Bouzid R (2015) Genome-wide identification and expression profiling of the late embryogenesis abundant genes in potato with emphasis on dehydrins. Mol Biol Rep 42(7):1163-1174. https://doi.org/10.1007/ s11033-015-3853-2

Chen K, Arora R (2013) Priming memory invokes seed stress-tolerance. Environ Exp Bot 94:33-45. https://doi.org/10.1016/j.envex pbot.2012.03.005

Chen H, Chu P, Zhou Y, Li Y et al (2012a) Overexpression of AtOGG1, a DNA glycosylase/AP lyase, enhances seed longevity and abiotic stress tolerance in Arabidopsis. J Exp Bot 63(11):41074121. https://doi.org/10.1093/jxb/ers093

Chen K, Fessehaie A, Arora R (2012b) Dehydrin metabolism is altered during seed osmopriming and subsequent germination under chilling and desiccation in Spinacia oleracea L. cv. Bloomsdale: possible role in stress tolerance. Plant Sci 183:27-36. https://doi. org/10.1016/j.plantsci.2011.11.002

Chen K, Fessehaie A, Arora R (2013) Aquaporin expression during seed osmopriming and post-priming germination in spinach. Biol Plant 57(1):193-198. https://doi.org/10.1007/s10535-012-0266-0

Chen D, Wang S, Cao B, Cao D et al (2016) Genotypic variation in growth and physiological response to drought stress and rewatering reveals the critical role of recovery in drought adaptation in maize seedlings. Front Plant Sci 6:1241. https://doi.org/ 10.3389/fpls.2015.01241
Chiappetta A, Muto A, Bruno L, Woloszynska M, Van Lijsebettens M, Bitonti MB (2015) A dehydrin gene isolated from feral olive enhances drought tolerance in Arabidopsis transgenic plants. Front Plant Sci 6:392. https://doi.org/10.3389/fpls.2015.00392

Chołuj D, Karwowska R, Ciszewska A, Jasińska M (2008) Influence of long-term drought stress on osmolyte accumulation in sugar beet (Beta vulgaris L.) plants. Acta Physiol Plant 30(5):679. https:// doi.org/10.1007/s11738-008-0166-2

Choudhury FK, Rivero RM, Blumwald E, Mittler R (2017) Reactive oxygen species, abiotic stress and stress combination. Plant $\mathrm{J}$ 90(5):856-867. https://doi.org/10.1111/tpj.13299

Crisp PA, Ganguly D, Eichten SR, Borevitz JO, Pogson BJ (2016) Reconsidering plant memory: intersections between stress recovery, RNA turnover, and epigenetics. Sci Adv 2(2):e1501340. https://doi.org/10.1126/sciadv.1501340

Dace H, Sherwin HW, Illing N, Farrant JM (1998) Use of metabolic inhibitors to elucidate mechanisms of recovery from desiccation stress in the resurrection plant Xerophyta humilis. Plant Growth Regul 24(3):171-177. https://doi.org/10.1023/A:1005883907800

Devi K, Prathima PT, Gomathi R, Manimekalai R, Lakshmi K, Selvi A (2019) Gene expression profiling in sugarcane genotypes during drought stress and rehydration. Sugar Tech 21(5):717-733. https://doi.org/10.1007/s12355-018-0687-y

Dien DC, Mochizuki T, Yamakawa T (2019) Effect of various drought stresses and subsequent recovery on proline, total soluble sugar and starch metabolisms in Rice (Oryza sativa L.) varieties. Plant Prod Sci 22(4):530-545. https://doi.org/10.1080/1343943X. 2019.1647787

Ding Y, Fromm M, Avramova Z (2012) Multiple exposures to drought 'train' transcriptional responses in Arabidopsis. Nat Commun 3(1):1-9. https://doi.org/10.1038/ncomms1732

Ding Y, Liu N, Virlouvet L, Riethoven JJ, Fromm M, Avramova Z (2013) Four distinct types of dehydration stress memory genes in Arabidopsis thaliana. BMC Plant Biol 13(1):229. https://doi. org/10.1186/1471-2229-13-229

Dobrá J, Vanková R, Havlová M, Burman AJ, Libus J, Štorchová H (2011) Tobacco leaves and roots differ in the expression of proline metabolism-related genes in the course of drought stress and subsequent recovery. J Plant Physiol 168(13):1588-1597. https:// doi.org/10.1016/j.jplph.2011.02.009

Farooq M, Wahid A, Kobayashi N, Fujita D, Basra SMA (2009) Plant drought stress: effects, mechanisms and management. Agron Sustain Dev 29:185-212. https://doi.org/10.1007/978-90-4812666-8_12

Farooq M, Wahid A, Lee DJ (2009) Exogenously applied polyamines increase drought tolerance of rice by improving leaf water status, photosynthesis and membrane properties. Acta Physiol Plant 31(5):937-945. https://doi.org/10.1007/s11738-009-0307-2

Farooq M, Irfan M, Aziz T, Ahmad I, Cheema SA (2013) Seed priming with ascorbic acid improves drought resistance of wheat. $\mathrm{J}$ Agron Crop Sci 199(1):12-22. https://doi.org/10.1111/j.1439037X.2012.00521.X

Farooq M, Romdhane L, Al Sulti MK, Rehman A, Al-Busaidi WM, Lee DJ (2020) Morphological, physiological and biochemical aspects of osmopriming-induced drought tolerance in lentil. J Agron Crop Sci 206(2):176-186. https://doi.org/10.1111/jac. 12384

Forti C, Shankar A, Singh A, Balestrazzi A, Prasad V, Macovei A (2020) Hydropriming and biopriming improve Medicago truncatula seed germination and upregulate DNA repair and antioxidant genes. Genes 11(3):242. https://doi.org/10.3390/genes11030242

Gallardo K, Job C, Groot SP, Puype M, Demol H, Vandekerckhove J, Job D (2001) Proteomic analysis of Arabidopsis seed germination and priming. Plant Physiol 126(2):835-848. https://doi.org/ 10.1104/pp.126.2.835 
Gamir J, Sánchez-Bel P, Flors V (2014) Molecular and physiological stages of priming: how plants prepare for environmental challenges. Plant Cell Rep 33(12):1935-1949. https://doi.org/10. 1007/s00299-014-1665-9

Gharechahi J, Sharifi G, Mirzaei M, Zeinalabedini M, Salekdeh GH (2019) Abiotic stress responsive microRNome and proteome: how correlated are they? Environ Exp Bot 165:150-160. https:// doi.org/10.1016/j.envexpbot.2019.05.014

Gill SS, Tuteja N (2010) Reactive oxygen species and antioxidant machinery in abiotic stress tolerance in crop plants. Plant Physiol Biochem 48(12):909-930. https://doi.org/10.1016/j.plaphy.2010. 08.016

Hayano-Kanashiro C, Calderón-Vázquez C, Ibarra-Laclette E, HerreraEstrella L, Simpson J (2009) Analysis of gene expression and physiological responses in three Mexican maize landraces under drought stress and recovery irrigation. PLoS one. https://doi.org/ 10.1371/journal.pone.0007531

Hossain MA, Li ZG, Hoque TS, Burritt DJ, Fujita M, Munné-Bosch S (2018) Heat or cold priming-induced cross-tolerance to abiotic stresses in plants: key regulators and possible mechanisms. Protoplasma 255(1):399-412. https://doi.org/10.1007/ s00709-017-1150-8

Huang L, Zhang L, Zeng R, Wang X et al (2020) Brassinosteroid priming improves peanut drought tolerance via eliminating inhibition on genes in photosynthesis and hormone signaling. Genes 11(8):919. https://doi.org/10.3390/genes11080919

Hura T, Hura K, Ostrowska A, Gadzinowska J, Grzesiak MT, Dziurka K, Dubas E (2018) Rieske iron-sulfur protein of cytochromeb6f is involved in plant recovery after drought stress. Environ Exp Bot 156:228-239. https://doi.org/10.1016/j.envexpbot. 2018.09.003

Hussain S, Rao MJ, Anjum MA, Ejaz S et al (2019) Oxidative stress and antioxidant defense in plants under drought conditions. In: Hasanuzzaman M, Hakeem KR, Nahar K, Alharby HF (eds) Plant abiotic stress tolerance. Springer, Cham, pp 207-219. https://doi.org/10.1007/978-3-030-06118-0_9

Iovieno P, Punzo P, Guida G, Mistretta C et al (2016) Transcriptomic changes drive physiological responses to progressive drought stress and rehydration in tomato. Front Plant Sci 7:371. https:// doi.org/10.3389/fpls.2016.00371

Jisha KC, Puthur JT (2016) Seed priming with BABA ( $\beta$-amino butyric acid): a cost-effective method of abiotic stress tolerance in Vigna radiata (L.) Wilczek. Protoplasma 253(2):277-289. https://doi.org/10.1007/s00709-015-0804-7

Jisha KC, Puthur JT (2016) Seed priming with beta-amino butyric acid improves abiotic stress tolerance in rice seedlings. Rice Sci 23(5):242-254. https://doi.org/10.1016/j.rsci.2016.08.002

Jisha KC, Puthur JT (2018) Seed hydropriming enhances osmotic stress tolerance potential in Vigna radiata. Agric Res 7(2):145151. https://doi.org/10.1007/s40003-018-0306-x

Jisha KC, Vijayakumari K, Puthur JT (2013) Seed priming for abiotic stress tolerance: an overview. Acta Physiol Plant 35(5):13811396. https://doi.org/10.1007/s11738-012-1186-5

Joshi R, Wani SH, Singh B, Bohra A et al (2016) Transcription factors and plants response to drought stress: current understanding and future directions. Front Plant Sci 7:1029. https://doi. org/10.3389/fpls.2016.01029

Khalaki MA, Moameri M, Lajayer BA, Astatkie T (2021) Influence of nano-priming on seed germination and plant growth of forage and medicinal plants. Plant Growth Regul 93:13-28. https://doi.org/10.1007/s10725-020-00670-9

Khan MN, Zhang J, Luo T, Liu J et al (2019) Seed priming with melatonin coping drought stress in rapeseed by regulating reactive oxygen species detoxification: antioxidant defense system, osmotic adjustment, stomatal traits and chloroplast ultrastructure perseveration. Ind Crops Prod 140:111597. https://doi.org/10.1016/j.indcrop.2019.111597

Khan MN, Khan Z, Luo T, Liu J et al (2020) Seed priming with gibberellic acid and melatonin in rapeseed: consequences for improving yield and seed quality under drought and non-stress conditions. Ind Crops Prod 156:112850. https://doi.org/10. 1016/j.indcrop.2020.112850

Kim JM, To TK, Ishida J, Matsui A, Kimura H, Seki M (2012) Transition of chromatin status during the process of recovery from drought stress in Arabidopsis thaliana. Plant Cell Physiol 53(5):847-856. https://doi.org/10.1093/pcp/pcs053

Kubala S, Wojtyla Ł, Quinet M, Lechowska K, Lutts S, Garnczarska M (2015) Enhanced expression of the proline synthesis gene P5CSA in relation to seed osmopriming improvement of Brassica napus germination under salinity stress. J Plant Physiol 183:1-12. https://doi.org/10.1016/j.jplph.2015.04.009

Kudo M, Kidokoro S, Yoshida T, Mizoi J et al (2017) Double overexpression of DREB and PIF transcription factors improves drought stress tolerance and cell elongation in transgenic plants. Plant Biotechnol J 15(4):458-471. https://doi.org/10. 1111/pbi.12644

Liu X, Challabathula D, Quan W, Bartels D (2019) Transcriptional and metabolic changes in the desiccation tolerant plant Craterostigma plantagineum during recurrent exposures to dehydration. Planta 249(4):1017-1035. https://doi.org/10.1007/s00425-018-3058-8

Liu SC, Jin JQ, Ma JQ, Yao MZ et al (2016) Transcriptomic analysis of tea plant responding to drought stress and recovery. PloS one. https://doi.org/10.1371/journal.pone.0147306

Macovei A, Balestrazzi A, Confalonieri M, Carbonera D (2010) The tyrosyl-DNA phosphodiesterase gene family in Medicago truncatula Gaertn.: Bioinformatic investigation and expression profiles in response to copper-and PEG-mediated stress. Planta 232(2):393-407. https://doi.org/10.1007/s00425-010-1179-9

Magwanga RO, Lu P, Kirungu JN, Lu H et al (2018) Characterization of the late embryogenesis abundant (LEA) proteins family and their role in drought stress tolerance in upland cotton. BMC Genet 19(1):6. https://doi.org/10.1186/s12863-017-0596-1

Marcos FC, Silveira NM, Marchiori PE, Machado EC, Souza GM, Landell MG, Ribeiro RV (2018) Drought tolerance of sugarcane propagules is improved when origin material faces water deficit. PLoS ONE 13(12):e0206716. https://doi.org/10.1371/journal. pone. 0206716

Martinez V, Nieves-Cordones M, Lopez-Delacalle M, Rodenas R et al (2018) Tolerance to stress combination in tomato plants: new insights in the protective role of melatonin. Molecules 23(3):535. https://doi.org/10.3390/molecules23030535

Martinez-Medina A, Flors V, Heil M, Mauch-Mani B et al (2016) Recognizing plant defense priming. Trends Plant Sci 21(10):818822. https://doi.org/10.1016/j.tplants.2016.07.009

Matos MC, Campos PS, Passarinho JA, Semedo JN, Marques NM, Ramalho JC, Ricardo CP (2010) Drought effect on photosynthetic activity, osmolyte accumulation and membrane integrity of two Cicer arietinum genotypes. Photosynthetica 48(2):303-312. https://doi.org/10.1007/s11099-010-0038-z

Mittler R, Vanderauwera S, Gollery M, Van Breusegem F (2004) Reactive oxygen gene network of plants. Trends Plant Sci 9(10):490498. https://doi.org/10.1016/j.tplants.2004.08.009

Miyashita K, Tanakamaru S, Maitani T, Kimura K (2005) Recovery responses of photosynthesis, transpiration, and stomatal conductance in kidney bean following drought stress. Environ Exp Bot 53(2):205-214. https://doi.org/10.1016/j.envexpbot.2004.03.015

Mouradi M, Bouizgaren A, Farissi M, Latrach L, Qaddoury A, Ghoulam C (2016) Seed osmopriming improves plant growth, nodulation, chlorophyll fluorescence and nutrient uptake in alfalfa (Medicago sativa L.) - rhizobia symbiosis under drought stress. 
Sci Hortic 213:232-242. https://doi.org/10.1016/j.scienta.2016. 11.002

Nawaz M, Wang Z (2020) Abscisic acid and glycine betaine mediated tolerance mechanisms under drought stress and recovery in Axonopus compressus: a new insight. Sci Rep 10(1):1-10. https://doi.org/10.1038/s41598-020-63447-0

Pandey V, Shukla A (2015) Acclimation and tolerance strategies of rice under drought stress. Rice Sci 22(4):147-161. https://doi.org/10. 1016/j.rsci.2015.04.001

Paparella S, Araújo SS, Rossi G, Wijayasinghe M, Carbonera D, Balestrazzi A (2015) Seed priming: state of the art and new perspectives. Plant Cell Rep 34(8):1281-1293. https://doi.org/10.1007/ s00299-015-1784-y

Parveen A, Liu W, Hussain S, Asghar J, Perveen S, Xiong Y (2019) Silicon priming regulates morpho-physiological growth and oxidative metabolism in Maize under drought stress. Plants 8(10):431. https://doi.org/10.3390/plants8100431

Peleg Z, Blumwald E (2011) Hormone balance and abiotic stress tolerance in crop plants. Curr Opin Plant Biol 14(3):290-295. https:// doi.org/10.1016/j.pbi.2011.02.001

Reddy AR, Chaitanya KV, Vivekanandan M (2004) Drought-induced responses of photosynthesis and antioxidant metabolism in higher plants. J Plant Physiol 161(11):1189-1202. https://doi. org/10.1016/j.jplph.2004.01.013

Rivas R, Falcão HM, Ribeiro RV, Machado EC, Pimentel C, Santos MG (2016) Drought tolerance in cowpea species is driven by less sensitivity of leaf gas exchange to water deficit and rapid recovery of photosynthesis after rehydration. S Afr J Bot 103:101-107. https://doi.org/10.1016/j.sajb.2015.08.008

Samota MK, Sasi M, Awana M, Yadav OP et al (2017) Elicitorinduced biochemical and molecular manifestations to improve drought tolerance in rice (Oryza sativa L.) through seed-priming. Front Plant Sci 8:934. https://doi.org/10.3389/fpls.2017. 00934

Schneider S, Turetschek R, Wedeking R, Wimmer M, Wienkoop S (2019) A protein-linger strategy keeps the plant on-hold after rehydration of drought-stressed Beta vulgaris. Front Plant Sci 10:381. https://doi.org/10.3389/fpls.2019.00381

Schwachtje J, Whitcomb SJ, Firmino AAP, Zuther E, Hincha DK, Kopka J (2019) Induced, imprinted, and primed responses to changing environments: does metabolism store and process information? Front Plant Sci 10:106. https://doi.org/10.3389/ fpls.2019.00106

Secchi F, Lovisolo C, Schubert A (2007) Expression of OePIP2. 1 aquaporin gene and water relations of Olea europaea twigs during drought stress and recovery. Ann Appl Biol 150:163-167. https://doi.org/10.1111/j.1744-7348.2007.00118.x

Sen A, Puthur JT (2020a) Influence of different seed priming techniques on oxidative and antioxidative responses during the germination of Oryza sativa varieties. Physiol Mol Biol Plants. https://doi.org/10.1007/s12298-019-00750-9

Sen A, Puthur JT (2020) Halo and UV-B priming influences various physiological and importantly yield parameters of Oryza sativa var. Vyttila 6. N Z J Crop Hortic Sci. https://doi.org/10.1080/ 01140671.2020 .1844765

Sen A, Challabathula D, Puthur JT (2020) UV-B priming of Oryza sativa seeds augments the innate tolerance potential in a tolerant variety more effectively toward $\mathrm{NaCl}$ and PEG stressors. J Plant Growth Regul. https://doi.org/10.1007/s00344-020-10177-2

Sengupta D, Guha A, Reddy AR (2013) Interdependence of plant water status with photosynthetic performance and root defense responses in Vigna radiata (L.) Wilczek under progressive drought stress and recovery. J Photochem Photobiol B 127:170181. https://doi.org/10.1016/j.jphotobiol.2013.08.004
Singh D, Laxmi A (2015) Transcriptional regulation of drought response: a tortuous network of transcriptional factors. Front Plant Sci 6:895. https://doi.org/10.3389/fpls.2015.00895

Sirhindi G, Mushtaq R, Gill SS, Sharma P, Abd Allah EF, Ahmad P (2020) Jasmonic acid and methyl jasmonate modulate growth, photosynthetic activity and expression of photosystem II subunit genes in Brassica oleracea L. Sci Rep 10(1):1-14. https://doi. org/10.1038/s41598-020-65309-1

Song Y, Lv J, Ma Z, Dong W (2019) The mechanism of alfalfa (Medicago sativa L.) response to abiotic stress. Plant Growth Regul. https://doi.org/10.1007/s10725-019-00530-1

Souza RP, Machado EC, Silva JAB, Lagôa AMMA, Silveira JAG (2004) Photosynthetic gas exchange, chlorophyll fluorescence and some associated metabolic changes in cowpea (Vigna unguiculata) during water stress and recovery. Environ Exp Bot 51(1):45-56. https://doi.org/10.1016/S0098-8472(03)00059-5

Srivastava AK, Lokhande VH, Patade VY, Suprasanna P, Sjahril R, D'Souza SF (2010) Comparative evaluation of hydro-, chemo-, and hormonal-priming methods for imparting salt and PEG stress tolerance in Indian mustard (Brassica juncea L.). Acta Physiol Plant 32(6):1135-1144. https://doi.org/10.1007/ s11738-010-0505-y

Tabassum T, Farooq M, Ahmad R, Zohaib A, Wahid A (2017) Seed priming and transgenerational drought memory improves tolerance against salt stress in bread wheat. Plant Physiol Biochem 118:362-369. https://doi.org/10.1016/j.plaphy.2017.07.007

Tabassum T, Ahmad R, Farooq M, Basra SMA (2018) Improving the drought tolerance in barley by osmopriming and biopriming. Int J Agric Biol 20(7):1597-1606. https://doi.org/10.17957/IJAB/ 15.0678

Takahashi F, Kuromori T, Sato H, Shinozaki K (2018) Regulatory gene networks in drought stress responses and resistance in plants. In: Iwaya-Inoue M, Sakurai M, Uemura M (eds) Survival strategies in extreme cold and desiccation. Springer, Singapore, pp 189-214. https://doi.org/10.1007/978-981-13-1244-1_11

Thomas DT, Puthur JT (2019) Amplification of abiotic stress tolerance potential in rice seedlings with a low dose of UV-B seed priming. Funct Plant Biol 46(5):455-466. https://doi.org/10.1071/ FP18258

Thomas TTD, Puthur JT (2020) UV-B priming enhances specific secondary metabolites in Oryza sativa (L.) empowering to encounter diverse abiotic stresses. Plant Growth Regul 92:169-180. https:// doi.org/10.1007/s10725-020-00628-x

Thomas TD, Dinakar C, Puthur JT (2020) Effect of UV-B priming on the abiotic stress tolerance of stress-sensitive rice seedlings: priming imprints and cross-tolerance. Plant Physiol Biochem 147:21-30. https://doi.org/10.1016/j.plaphy.2019.12.002

To TK, Kim JM (2014) Epigenetic regulation of gene responsiveness in Arabidopsis. Front Plant Sci 4:548. https://doi.org/10.3389/ fpls.2013.00548

Wang XS, Zhu HB, Jin GL, Liu HL, Wu WR, Zhu J (2007) Genomescale identification and analysis of LEA genes in rice (Oryza sativa L.). Plant Sci 172(2):414-420. https://doi.org/10.1016/j. plantsci.2006.10.004

Wang WS, Pan YJ, Zhao XQ, Dwivedi D et al (2010) Drought-induced site-specific DNA methylation and its association with drought tolerance in rice (Oryza sativa L.). J Exp Bot 62(6):1951-1960. https://doi.org/10.1093/jxb/erq391

Wang X, Vignjevic M, Jiang D, Jacobsen S, Wollenweber B (2014) Improved tolerance to drought stress after anthesis due to priming before anthesis in wheat (Triticum aestivum L.) var Vinjett. J Exp Bot 65(22):6441-6456. https://doi.org/10.1093/jxb/eru362

Wang X, Mao Z, Zhang J, Hemat M et al (2019) Osmolyte accumulation plays important roles in the drought priming induced tolerance to post-anthesis drought stress in winter wheat (Triticum 
aestivum L.). Environ Exp Bot 166:1004. https://doi.org/10. 1016/j.envexpbot.2019.103804

Waterworth WM, Masnavi G, Bhardwaj RM, Jiang Q, Bray CM, West CE (2010) A plant DNA ligase is an important determinant of seed longevity. Plant J 63(5):848-860. https://doi.org/10.1111/j. 1365-313X.2010.04285.X

Wedeking R, Maucourt M, Deborde C, Moing A, Gibon Y, Goldbach HE, Wimmer MA (2018) 1H-NMR metabolomic profiling reveals a distinct metabolic recovery response in shoots and roots of temporarily drought-stressed sugar beets. PloS one. https://doi. org/10.1371/journal.pone.0196102

Wojtyla Ł, Lechowska K, Kubala S, Garnczarska M (2016) Molecular processes induced in primed seeds-increasing the potential to stabilize crop yields under drought conditions. J Plant Physiol 203:116-126. https://doi.org/10.1016/j.jplph.2016.04.008

Wu W, Liu L, Yan Y (2019) Transcription factor TERF1 regulates nuclear genes expression through miRNAs in tobacco under drought stress condition. Plant Growth Regul 89(3):251-258. https://doi.org/10.1007/s10725-019-00532-z

Xiao B, Huang Y, Tang N, Xiong L (2007) Over-expression of a LEA gene in rice improves drought resistance under the field conditions. Theor Appl Genet 115(1):35-46. https://doi.org/10.1007/ s00122-007-0538-9

Xu Y, Hu W, Liu J, Song S et al (2020) An aquaporin gene MaPIP2-7 is involved in tolerance to drought, cold and salt stresses in transgenic banana (Musa acuminata L.). Plant Physiol Biochem 147:66-76. https://doi.org/10.1016/j.plaphy.2019.12.011

Yi XP, Zhang YL, Yao HS, Luo HH, Gou L, Chow WS, Zhang WF (2016) Rapid recovery of photosynthetic rate following soil water deficit and re-watering in cotton plants (Gossypium herbaceum L.) is related to the stability of the photosystems. J Plant Physiol 194:23-34. https://doi.org/10.1016/j.jplph.2016.01.016

Zandalinas SI, Balfagón D, Arbona V, Gómez-Cadenas A (2017) Modulation of antioxidant defense system is associated with combined drought and heat stress tolerance in citrus. Front Plant Sci 8:953. https://doi.org/10.3389/fpls.2017.00953

Zhang JY, Cruz De Carvalho MH, Torres-Jerez I, Kang YUN et al (2014) Global reprogramming of transcription and metabolism in Medicago truncatula during progressive drought and after rewatering. Plant Cell Environ 37(11):2553-2576. https://doi.org/ $10.1111 /$ pce. 12328

Zhang X, Lei L, Lai J, Zhao H, Song W (2018) Effects of drought stress and water recovery on physiological responses and gene expression in maize seedlings. BMC Plant Biol 18(1):68. https://doi. org/10.1186/s12870-018-1281-x

Zhang F, Yu J, Johnston CR, Wang Y et al (2015) Seed priming with polyethylene glycol induces physiological changes in sorghum (Sorghum bicolor L. Moench) seedlings under suboptimal soil moisture environments. PLoS One 10(10):e0140620. https://doi. org/10.1371/journal.pone.0140620

Zheng J, Fu J, Gou M, Huai J et al (2010) Genome-wide transcriptome analysis of two maize inbred lines under drought stress. Plant Mol Biol 72(4-5):407-421. https://doi.org/10.1007/ s11103-009-9579-6

Zheng M, Tao Y, Hussain S, Jiang Q et al (2016) Seed priming in dry direct-seeded rice: consequences for emergence, seedling growth and associated metabolic events under drought stress. Plant Growth Regul 78(2):167-178. https://doi.org/10.1007/ s10725-015-0083-5

Zhou R, Yu X, Ottosen CO, Rosenqvist E et al (2017) Drought stress had a predominant effect over heat stress on three tomato cultivars subjected to combined stress. BMC Plant Biol 17(1):24. https://doi.org/10.1186/s12870-017-0974-X

Zhu H, Zhou Y, Zhai H, HE S, Zhao N, Liu Q (2019) Transcriptome profiling reveals insights into the molecular mechanism of drought tolerance in sweet potato. J Integr Agric 18(1):9-23. https://doi.org/10.1016/S2095-3119(18)61934-3

Publisher's Note Springer Nature remains neutral with regard to jurisdictional claims in published maps and institutional affiliations. 